University for Business and Technology in Kosovo

UBT Knowledge Center

UBT International Conference

2015 UBT International Conference

Nov 7th, 9:00 AM - 5:00 PM

\title{
Assessment of wood processing engineers by requirements of leading manufacturing entities in Albania
}

\author{
Ramadan Topuzi \\ Agricultural University of Tirana, dan_topuzi@live.it \\ Arden Bejtja \\ Agricultural University of Tirana, arbenbejtja@yahoo.fr
}

Follow this and additional works at: https://knowledgecenter.ubt-uni.net/conference

Part of the Civil Engineering Commons, and the Structural Engineering Commons

\section{Recommended Citation}

Topuzi, Ramadan and Bejtja, Arden, "Assessment of wood processing engineers by requirements of leading manufacturing entities in Albania" (2015). UBT International Conference. 72.

https://knowledgecenter.ubt-uni.net/conference/2015/all-events/72

This Event is brought to you for free and open access by the Publication and Journals at UBT Knowledge Center. It has been accepted for inclusion in UBT International Conference by an authorized administrator of UBT Knowledge Center. For more information, please contact knowledge.center@ubt-uni.net. 


\title{
Assessment of wood processing engineers by requirements of leading manufacturing entities in Albania
}

\author{
Ramadan Topuzi ${ }^{1}$, Arben Bejtja ${ }^{2}$ \\ ${ }^{1,2}$ Agricultural University of Tirana, Department of Wood Industry, Tirana-Albania \\ dan_topuzi@live.it ${ }^{1}$, arbenbejtja@yahoo.fr ${ }^{2}$
}

\begin{abstract}
In Albania a significant number of wood-processing engineers exercise this profession in the field of manufacturing and trading of furniture. In this sector exercise their activity over 800 manufacturing entities distributed across the country with about 9,000 employees. The main purpose of the study is the assessment of wood processing engineers as perceived by the manufacturing entities and their adaptation to the requirements of the labor market.

The data collected through a structured questionnaire for this purpose, are thrown into a database (where they are analy zed to generate the results given in this paper. The selection of the respondents is made by purposeful sampling, as access to a non-probability sample. The surveying method chosen is the "face to face" one. The material prepared refers to 100 surveys carried out throughout Albania. There have been selected the main manufacturing entities that operate in the field of manufacturing and trading of furniture and which are well-known in the market.

The respondents are mainly wood processing engineers, experienced managers of manufacturing entities, economists etc., exercising the above mentioned profession. The study shows that the market needs wood processing engineers who are professionally skilled. The most part of respondents express themselves in favor of engineers who have carried out Master Studies in this profile. They think that scientific and economic training also matter in the formation of engineers. In Master degrees, the courses related to the field of architecture are valued higher than others. Respondents also think that Professional practice of students is paramount in the formation of a fully trained engineer. The most effective way to this goal is that the professional practice should be realized in the manufacturing, and is best if carried out through paid employment. Elements completing the profile of the wood processing engineer are also considered the knowledge of foreign languages and new technologies.
\end{abstract}

Keywords:, manufacturing entity, practice, market, wood processing.

\section{Introduction}

In the Faculty of Forestry Sciences, the Wood Industry Department in Albania, over the years there have been graduated a significant number of wood processing engineers. This Department operates on the basis of the curriculum, developed by the Academic Staff of the Department and approved by the Council of Professors and the University Senate.

On the other hand, in our country operate a significant number of wood processing production entities, with a geographical distribution across the territory. These subjects constitute real opportunities for the employment of engineers today and in the future, in other words, they constitute the labor market. The market includes a significant number of wood processing engineers who practice this profession. Engineers result; employed in management positions and a good part of them are entrepreneurs and exercise their activities in the field of manufacturing and trading of furniture.

The main purpose of this study is the evaluation of wood processing engineers as perceived by manufacturing entities, considering their opinion and adaptation of the curriculum to the requirements of the labor market. This will be achieved through assessment provided by the respondents to the curriculum of the Wood Industry Department, presented to them by means of questionnaires. Data collection was conducted through structured questionnaires for this purpose, where respondents express their opinion regarding the curriculum and expectations they have towards the Wood Processing Engineers. 


\section{Methodology}

The methodology followed for the implementation of this study is:

- Identification of entities operating in the wood processing industry in Albania.

- Development of questionnaires needed for this purpose, through which, all manufacturing entities express their opinion for the wood processing engineers regarding the curriculum.

- Direct site contact with the manufacturing entities and completion of questionnaires, through face to face surveys.

- Data analy sis, their comparison and finding of adaptation ways

\section{Data Collection}

After site verification and the data collected it results that: In Albania over 800 entities with approx. 9,000 employees, exercise their activity in the field of manufacturing and trading of furniture, scattered across the country. There are about 70 Wood Processing engineers exercising this activity throughout Albania.

This study is based on survey s carried out in the country with leading manufacturing entities op erating in the field of manufacturing and trading of furniture, and which are prominent in the market. The material prepared refers to 100 surveys conducted throughout Albania, in the most prominent manufacturing entities. To conduct surveys were selected main business in major cities in proportion to the number of these businesses nationwide. Most of them are located in Tirana, Fushe Kruja, Durres, Shkodra, Lezha, Elbasan, Fier, Vlora, Korca etc. Table 1 provides summary data of subjects identified and of those where surveys were conducted for each city.

Table 1. Number of respondents for each city

\begin{tabular}{clcclc}
\hline & & $\begin{array}{c}\text { The number of } \\
\text { surveys conducted }\end{array}$ & No & \multicolumn{1}{c}{ City } & $\begin{array}{c}\text { The number of } \\
\text { surveys conducted }\end{array}$ \\
\hline 1 & Bajram Curri & 1 & 15 & Lushnjë & 2 \\
2 & Pukë & 1 & 16 & Elbasan & 5 \\
3 & Kukës & 3 & 17 & Berat & 3 \\
4 & Shkodër & 4 & 18 & Fier & 6 \\
5 & Lezhë & 3 & 19 & Vlorë & 5 \\
6 & Rrëshen & 1 & 20 & Gramsh & 1 \\
7 & Peshkopi & 1 & 21 & Librazhd & 1 \\
8 & Burrel & 2 & 22 & Çorovodë & 1 \\
9 & Fushë Krujë & 14 & 23 & Pogradec & 2 \\
10 & Krujë & 3 & 24 & Korçë & 3 \\
11 & Tiranë & 21 & 25 & Ersekë & 1 \\
12 & Kamëz & 2 & 26 & Përmet & 1 \\
13 & Durrës & 6 & 27 & Gjirokastër & 2 \\
14 & Kavajë & 3 & 28 & Sarandë & 2 \\
\hline & & & TOTAL & 100 \\
\hline
\end{tabular}

Data were collected through a structured questionnaire for this purpose wherein are included open and filtering questions. The questionnaire is intended to approach a common/usable format to enable the creation of a profile of the engineer closer to the labor market needs. The data collected through these questionnaires are thrown into a database to be further analyzed and to fulfill the study objectives. 
International Conference on Civil Engineering, Infrastructure and Environment, Nov 2015

\section{Data Analysis And Results}

Surveys were conducted mainly with entrepreneurs/managers of manufacturing entities, but also with employed engineers and economists. To create a clearer picture also the engineers who run the activity themselves are considered employed. Table 2 provides data on subjects where surveys were conducted, the number of engineers employed and the market needs.

\begin{tabular}{|c|c|c|c|c|c|c|c|c|c|}
\hline $\begin{array}{l}\text { Cod } \\
\text { e of } \\
\text { the } \\
\text { resp } \\
\text { onde } \\
\text { nts }\end{array}$ & ت্ & 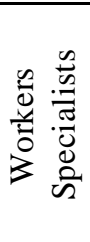 & 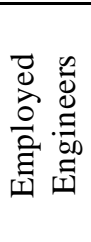 & 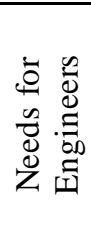 & $\begin{array}{l}\text { Code } \\
\text { of the } \\
\text { respo } \\
\text { ndent } \\
\quad \mathrm{s}\end{array}$ & 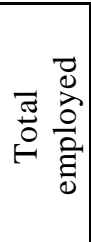 & 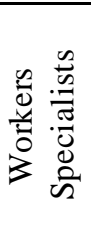 & 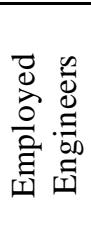 & 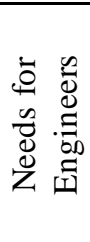 \\
\hline A10 & 6 & 6 & 0 & 1 & A106 & 15 & 14 & 1 & 0 \\
\hline A12 & 50 & 48 & 2 & 0 & A108 & 14 & 14 & 0 & 1 \\
\hline A13 & 18 & 17 & 1 & 0 & A110 & 6 & 5 & 1 & 0 \\
\hline A15 & 8 & 7 & 1 & 1 & A114 & 4 & 3 & 1 & 0 \\
\hline A18 & 7 & 7 & 0 & 1 & A121 & 8 & 7 & 1 & 0 \\
\hline A21 & 23 & 23 & 0 & 1 & A130 & 18 & 18 & 0 & 0 \\
\hline A23 & 60 & 58 & 2 & 0 & A131 & 170 & 170 & 0 & 0 \\
\hline A24 & 13 & 13 & 0 & 1 & A132 & 30 & 29 & 1 & 0 \\
\hline A26 & 12 & 11 & 1 & 1 & A138 & 7 & 7 & 0 & 0 \\
\hline A30 & 5 & 5 & 0 & 1 & A139 & 6 & 5 & 1 & 0 \\
\hline A31 & 13 & 12 & 1 & 1 & A141 & 7 & 6 & 1 & 0 \\
\hline A33 & 12 & 12 & 0 & 0 & A145 & 8 & 8 & 0 & 0 \\
\hline A34 & 11 & 10 & 1 & 0 & A147 & 5 & 5 & 0 & 0 \\
\hline A36 & 60 & 56 & 4 & 0 & A149 & 5 & 5 & 0 & 1 \\
\hline A37 & 30 & 30 & 0 & 1 & A151 & 6 & 6 & 0 & 1 \\
\hline A38 & 13 & 11 & 2 & 0 & A153 & 6 & 6 & 0 & 1 \\
\hline A39 & 40 & 39 & 1 & 0 & A154 & 7 & 7 & 0 & 1 \\
\hline A40 & 20 & 19 & 1 & 1 & A158 & 7 & 7 & 0 & 1 \\
\hline A42 & 17 & 17 & 0 & 1 & A160 & 5 & 4 & 1 & 0 \\
\hline A43 & 33 & 32 & 1 & 0 & A161 & 8 & 8 & 0 & 1 \\
\hline A45 & 40 & 37 & 3 & 0 & A164 & 80 & 79 & 1 & 0 \\
\hline A46 & 40 & 39 & 1 & 1 & A170 & 25 & 25 & 0 & 1 \\
\hline A47 & 20 & 19 & 1 & 0 & A172 & 6 & 6 & 0 & 1 \\
\hline A49 & 40 & 40 & 0 & 1 & A173 & 26 & 26 & 0 & 1 \\
\hline A51 & 12 & 11 & 1 & 0 & A175 & 7 & 7 & 0 & 1 \\
\hline A52 & 8 & 7 & 1 & 0 & A177 & 10 & 10 & 0 & 1 \\
\hline A54 & 14 & 14 & 0 & 0 & A178 & 2 & 2 & 0 & 0 \\
\hline A56 & 8 & 8 & 0 & 0 & A179 & 20 & 20 & 0 & 1 \\
\hline A57 & 7 & 7 & 0 & 0 & A184 & 7 & 7 & 0 & 1 \\
\hline A59 & 15 & 14 & 1 & 0 & A188 & 10 & 10 & 0 & 1 \\
\hline A61 & 12 & 12 & 0 & 0 & A194 & 4 & 4 & 0 & 0 \\
\hline A62 & 10 & 9 & 1 & 0 & A195 & 15 & 15 & 0 & 1 \\
\hline A72 & 5 & 5 & 0 & 0 & A198 & 15 & 14 & 1 & 0 \\
\hline A73 & 5 & 5 & 0 & 0 & A199 & 10 & 10 & 0 & 1 \\
\hline A74 & 7 & 7 & 0 & 1 & A200 & 12 & 12 & 0 & 1 \\
\hline A77 & 11 & 11 & 0 & 0 & A205 & 14 & 14 & 0 & 1 \\
\hline A78 & 17 & 16 & 1 & 0 & A208 & 35 & 35 & 0 & 1 \\
\hline A81 & 16 & 15 & 1 & 0 & A209 & 12 & 12 & 0 & 1 \\
\hline
\end{tabular}


International Conference on Civil Engineering, Infrastructure and Environment, Nov 2015

\begin{tabular}{|c|c|c|c|c|} 
A82 & 7 & 7 & 0 & 0 \\
\hline A83 & 8 & 8 & 0 & 0 \\
\hline A84 & 14 & 14 & 0 & 0 \\
\hline A85 & 15 & 15 & 0 & 1 \\
\hline A86 & 10 & 9 & 1 & 0 \\
\hline A89 & 15 & 15 & 0 & 1 \\
\hline A90 & 10 & 9 & 1 & 0 \\
\hline A91 & 8 & 7 & 1 & 1 \\
\hline A92 & 9 & 9 & 0 & 0 \\
\hline A96 & 30 & 30 & 0 & 0 \\
\hline A97 & 8 & 8 & 0 & 0 \\
\hline & & & & \\
\hline
\end{tabular}

\begin{tabular}{|c|c|c|c|c|} 
A210 & 5 & 5 & 0 & 0 \\
\hline A216 & 5 & 5 & 0 & 1 \\
\hline A217 & 50 & 49 & 1 & 0 \\
\hline A221 & 34 & 33 & 1 & 0 \\
\hline A228 & 17 & 16 & 1 & 0 \\
\hline A230 & 50 & 50 & 0 & 1 \\
\hline A232 & 7 & 7 & 0 & 0 \\
\hline A241 & 30 & 29 & 1 & 0 \\
\hline A248 & 6 & 6 & 0 & 0 \\
\hline A249 & 12 & 11 & 1 & 1 \\
\hline A251 & 22 & 21 & 1 & 0 \\
\hline $\begin{array}{c}\text { TOT } \\
\text { AL }\end{array}$ & $\mathbf{1 8 3 4}$ & $\mathbf{1 7 8 4}$ & $\mathbf{5 0}$ & $\mathbf{4 1}$ \\
\hline
\end{tabular}

Table 2. Summary data on the subjects surveyed

The data show; that only to surveyed entities the needs for Wood Processing engineers are also for 41 versus 50 engineers employed.

\section{No of employees and the need for engineers}

1834

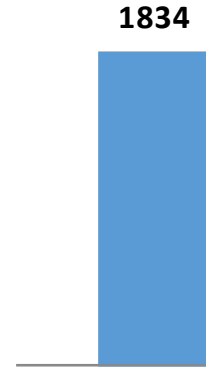

Total employed
1784

50

41

Workers Specialists Employed Engineers Needs for Engineers

Figure 1. The number of employ ees and the need for engineers

\section{Curriculum Assessment}

In the following analysis it is made an assessment in a generalized form of both levels of study for groups of curriculums as follows:

General training subjects, Basic training engineering subjects, Business economy oriented subjects, Vocational training subjects, Other subjects that are practically optional.

Data collected from the survey are thrown into a database and it is conducted their analy sis. For each of the groups, it is given the amount of assessment points and an overall average that shows how they are quoted by importance, as perceived by the respondents. For ease of calculation they are marked 
with numbers, because the assessment in the questionnaire is received in words; Paramount/5, Important/4 Less Important/3 and Insignificant/1. The results are summarized in the following tables.

Table 3: Assessment by the respondents, for first level Bachelor curriculum subjects Subjects taught in the first level Bachelor

Scoring by importance, in increasing order $1,3,4,5$

\begin{tabular}{llllll}
$\begin{array}{l}\text { The grouping } \\
\text { of subjects }\end{array}$ & $\begin{array}{l}\text { General } \\
\text { training } \\
\text { subjects }\end{array}$ & $\begin{array}{l}\text { Basic training } \\
\text { engineering } \\
\text { subjects }\end{array}$ & $\begin{array}{l}\text { Business economy } \\
\text { oriented subjects }\end{array}$ & $\begin{array}{l}\text { Vocational } \\
\text { training } \\
\text { subjects }\end{array}$ & $\begin{array}{l}\text { Other } \\
\text { subjects }\end{array}$ \\
$\begin{array}{l}\text { No of subjects } \\
\text { Total of points }\end{array}$ & 7 & 9 & 10 & 16 & 11 \\
$\begin{array}{l}\text { Overall } \\
\text { average }\end{array}$ & 3.7171 & 4607 & 3853 & 6877 & 3715 \\
\hline
\end{tabular}

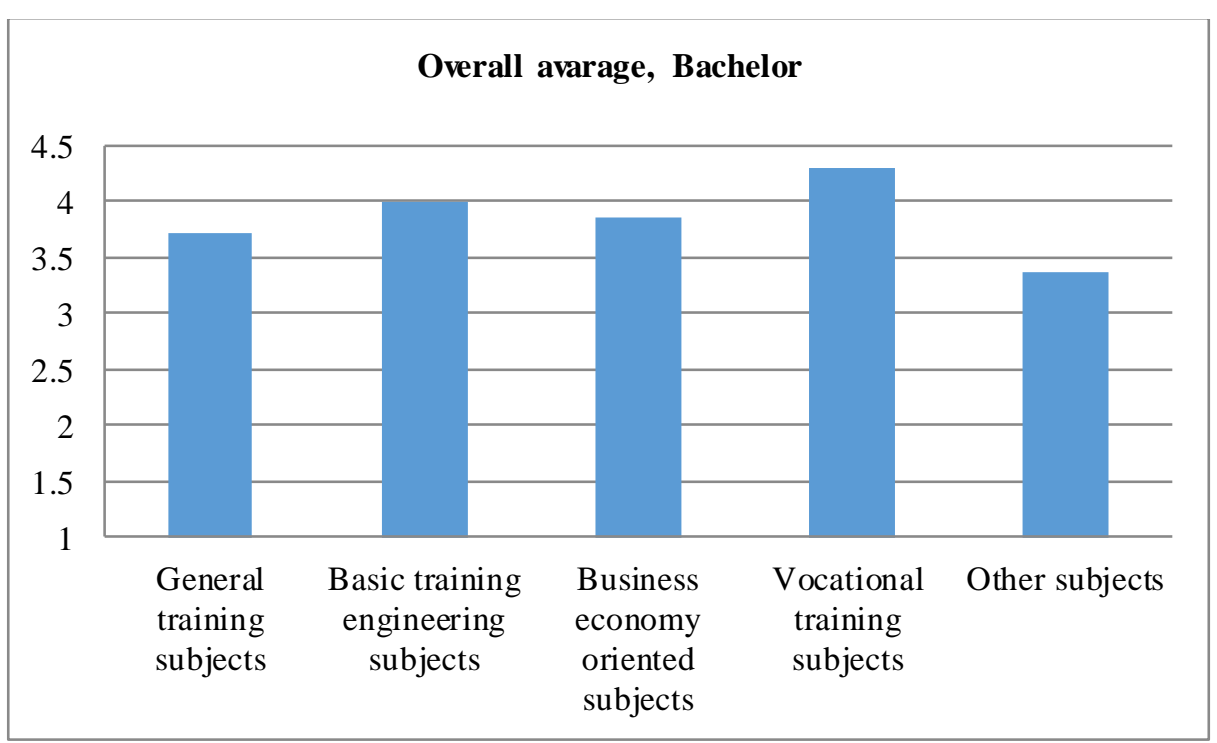

Fig. 2: Average data for the evaluation of the curriculum of the First Level Bachelor (Degree)

The graph shows a higher rating for the vocational training subiects. The respondents list as second in importance the basic engineering subjects which again vary by profession. Later, they list the economy-business oriented subjects. 
Tab. 4: Assessment by the respondents of the curriculum subjects in the M Sc level Subjects taught in the Master of Science

Scoring by importance, in increasing order 1, 3, 4, 5

\begin{tabular}{ccc}
\hline $\begin{array}{c}\text { The grouping of } \\
\text { subjects }\end{array}$ & General qualification subjects & $\begin{array}{c}\text { Specialty subjects and other } \\
\text { subjects }\end{array}$ \\
Number of subjects & 8 & 11 \\
Total of points & 3148 & 4450 \\
\hline Overall average & 3.935 & 4.0495 \\
\hline
\end{tabular}

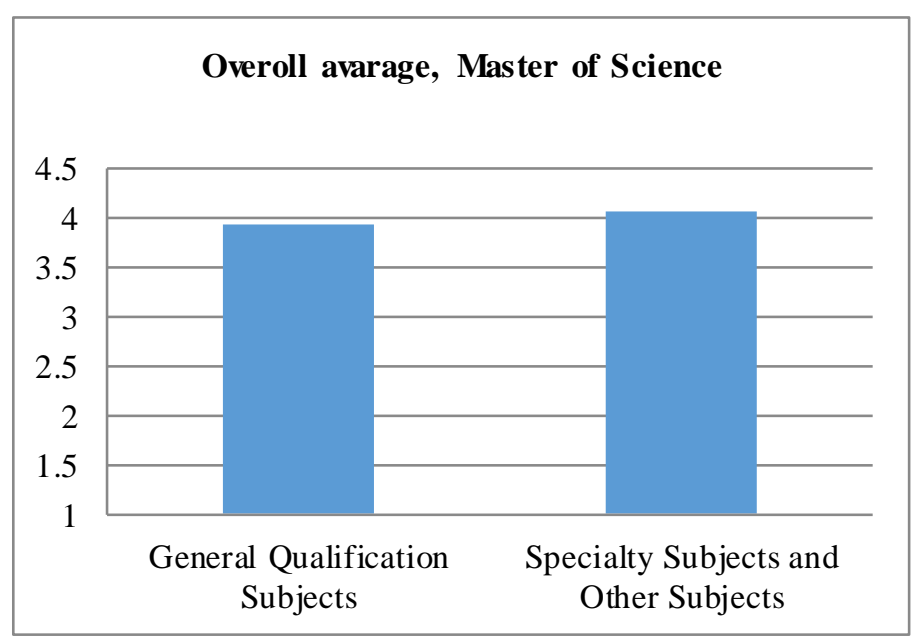

Fig. 3: Assessment by the respondents of the curriculum subjects in the MSc level

As shown by the graph, related to subjects in the MSc, the respondents underestimate the above specialty training subjects as compared with the general knowledge subjects. Thus, in their opinion, the market needs specialized engineers in the field of Wood Industry, professionally capable. The difference is small due to the overlapping of subjects.

Tab. 5: Assessment by the respondents of the curriculum subjects that are thought to be developed in the Master of Professional Studies.

\begin{tabular}{lllll}
\hline \multicolumn{5}{c}{ Subjects to be developed in the Master of Professional Studies. Scoring by } \\
importance, in increasing order 1,3, 4, 5
\end{tabular}




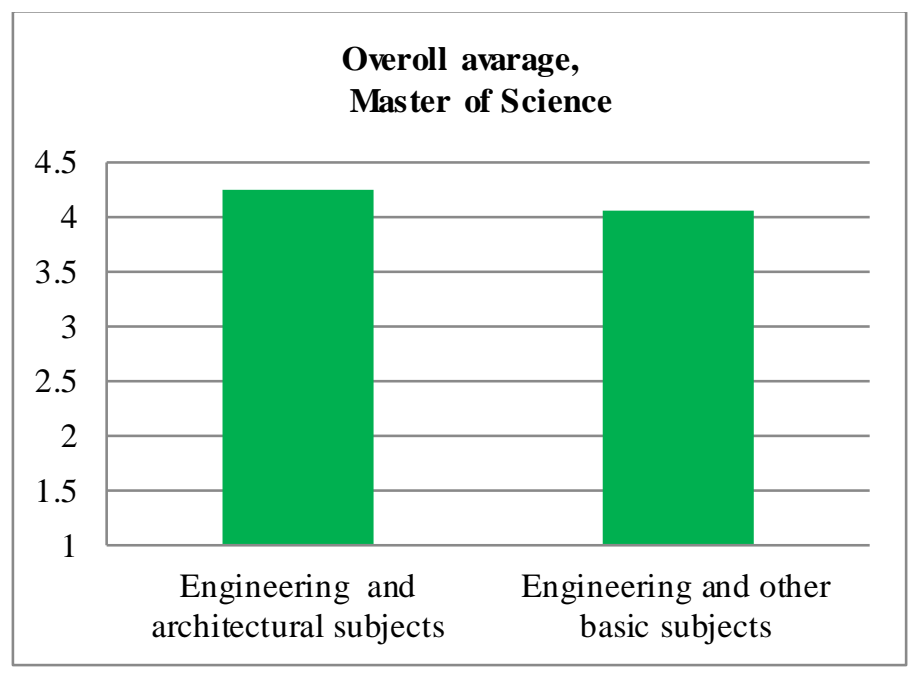

Fig. 4: Assessment by the respondents of the curriculum subjects that are thought to be developed in the Master of Professional Studies.

Studying for Professional Studies Master Degree has aimed to obtain a preliminary assessment of the manufacturing entities as basically, this level of studies has not yet been applied. So far it is drafted the Curriculum for this level of studies which is considered to be soon implemented. As above are estimated the architectural training subjects.

\section{Assessment of some elements of unive rsity training}

The assessment of the respondents on the education level of wood processing engineers. In the Faculty of Forestry Sciences, Department of Wood Industry in Albania, for years it has been applied the educational sy stem under the Charter of Bologna. In practice there are two levels of study, Bachelor (3 years) and Master of Science (2 years). Professional Master (1.5 y ears) has not yet been applied. So far it has only been designed the Curriculum which is thought to be implemented soon. Through the question; How would you rate the engineer in terms of education? Respondents have received as follows:

Table 6. Number of answers by 100 respondents

\begin{tabular}{llllll}
\hline $\begin{array}{l}\text { Education level of } \\
\text { engineers }\end{array}$ & Paramount & Important & $\begin{array}{l}\text { Less } \\
\text { Importan } \\
\mathrm{t}\end{array}$ & $\begin{array}{l}\text { Insignifican } \\
\mathrm{t}\end{array}$ & $\begin{array}{l}\text { Total } \\
\text { respondents }\end{array}$ \\
\hline $\begin{array}{l}3 \text { year Bachelor } \\
\begin{array}{l}4.5 \text { year Professional } \\
\text { Master }\end{array}\end{array}$ & 15 & 36 & $\mathbf{3 7}$ & 12 & 100 \\
$\begin{array}{l}\text { y year Scientific } \\
\text { Master }\end{array}$ & $\mathbf{7 2}$ & $\mathbf{5 1}$ & 6 & 0 & 100 \\
\hline
\end{tabular}




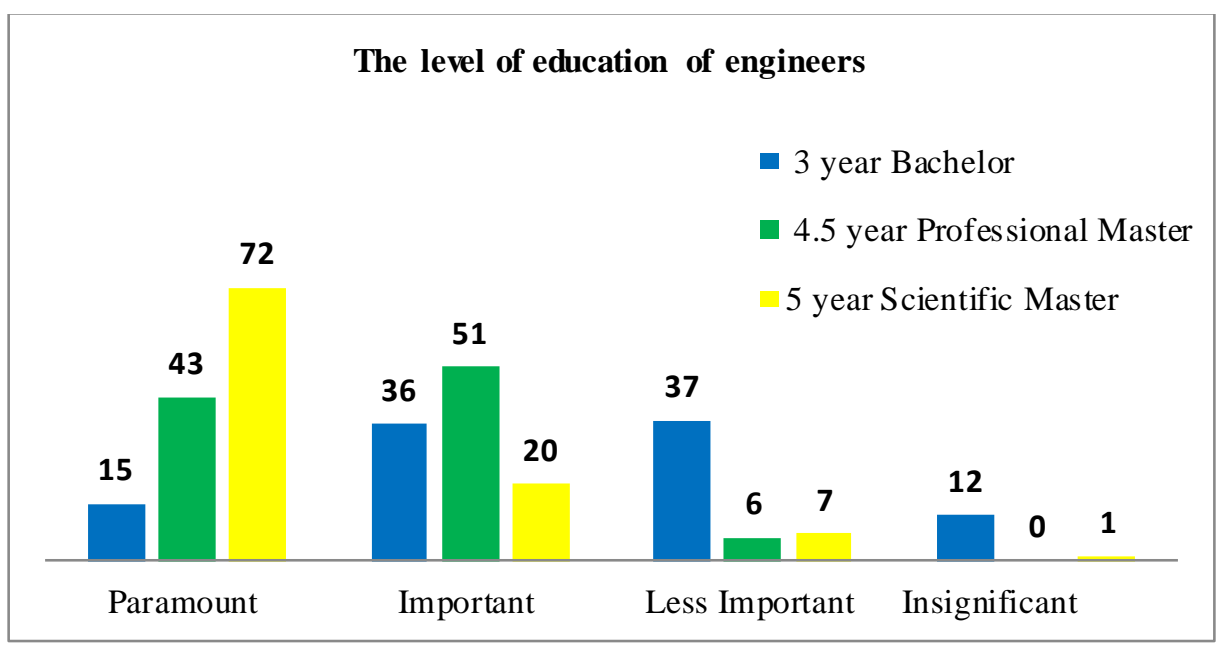

Fig. 5: The reating for the level ol education of engineers

By analyzing the responses received from respondents it turns out that:

Regarding the Bachelor level $37 \%$ of the respondents think that this level is less important to their business. While $36 \%$ of them say it is important and only $15 \%$ of them think that this level is paramount. This means that the engineers who have completed this level of study are viewed with reservations from the labor market. The market is not fully ready to accept " 3 year term engineers". For the Professional Master level which is expected to be applied soon, respondents have other expectations assessing higher its curriculum. Specifically there are $51 \%$ who say that it is important and $43 \%$ who think that it is paramount. The assessment in this case goes not only for the duration of studies, but mainly for the professional training courses and especially for architectural training courses.

In the MSc level the paramount assessment goes to $72 \%$. In this case the duration of the studies is maximally assessed because this difference is not so evident in the curriculum. It should be considered that a good portion of the respondents are familiar with the earlier idea of the study tradition on a 4year timeline.

\section{Conclusions and Recommendations}

- $\quad$ Respondents express themselves with reservations about the engineers who perform first level 3 -year Bachelor studies. The majority of respondents are in favor of engineers who have completed Master studies in this profile. In Master levels it is also assessed the extension in time of studies ie. 4.5 up to 5 years in total.

- Vocational training courses "vocational courses" are considered as paramount by the majority of respondents. They also think that the scientific and economic training are important in the formation of engineers. In Master levels, courses related to the field of architecture are valued higher than others. As an elements completing the profile of wood processing engineers is also considered the knowledge of foreign languages and new technologies.

- The current labor market in the field of manufacturing and trading of furniture needs professionally skilled engineers.

- We should aim to improve the curriculum to increase the practicality of implementing the knowledge gained by being closer to the profession of the wood processing engineer.

- The Faculty should focus its attention on the progress of engineers after graduation, by intensifying the cooperation with them and simultaneously with the requirements and labor market trends. 
International Conference on Civil Engineering, Infrastructure and Environment, Nov 2015

\section{Lite rature}

1. National consultation with international participation. Academic restructuring and institutional assessment of the Agricultural University of Tirana. Tirana (2003)

2. The strategic plan of the Agricultural University of Tirana. Tirana (2005)

3. The need for Wood Processing engineers in the manufacturing entities of Tirana. Topuzi R Bejtja A.(2015)

4. Elements of engineering training and their assessment by the labor market. Topuzi R Bejtja A Peri L.(2015) 